\title{
Students'Ability in Analyzing by Using a Flow Proof to Solve Problems in Real-Analysis Lecture
}

\author{
$1^{\text {st }}$ Helma \\ Mathematics Department \\ Universitas Negeri Padang \\ Padang, Indonesia \\ helma667@yahoo.co.id
}

\author{
$2^{\text {nd }}$ Dewi Murni \\ Mathematics Department \\ Universitas Negeri Padang \\ Padang, Indonesia \\ murnimatunp@yahoo.co.id
}

\author{
$3^{\text {rd }}$ Muhammad Subhan \\ Mathematics Department \\ Universitas Negeri Padang \\ Padang, Indonesia \\ 13subhan@gmail.com
}

\begin{abstract}
Real analysis is one of subjects that help the students to experience critical thinking processes. Students must understand mathematical definitions and theorems in order to solve problems and perform a process of analytical thinking, so that their analysis will be developed to the given problems. The research that has been done showed that students' ability in analyzing can be improved by using Flow Proof in a preliminary analysis, but not their ability in narrating the proof yet.
\end{abstract}

Keywords-Real Analysis, critical thinking, Flow Proof, preliminary analysis

\section{INTRODUCTION}

Real Analysis course is very necessary for undergraduate students majoring mathematics and mathematics education. Bartle [1] states 'The study of real analysis is indispensable for a prospective graduate student of pure or applied mathematics'. Real Analysis course aims to form and drill students' rational and intuitive understanding.

The competence to be achieved after studying this course is that students are able to analyze problems, think logically in solving problems, i.e. by using existing definitions/theorems/corollaries/lemmas, and writing the solution of the problem in a correct logic sequence. Refer to the reference number, as in [1], Real Analysis aims "to help the reader gain experience in the type of critical thought that is used in this deductive process".

Students must understand definitions and theorems to solve the problems in Real Analysis and perform a process of analitycal thinking, which is often called the preliminary analysis. After the preliminary analysis, students construct the proof based on the preliminary analysis.

Based on their understanding ability, students can develop an analysis of the given problem. Students can understand and define definitions/theorems with their own language. They can interpret and explain reason and communicate their understanding, as well as can make connections between definitions and theorems and use them to solve mathematical problems.

If students understand and are able to define definitions and theorems in Real Analysis, students learn how to analyze a statement and use it to solve a problem. Students need to find and describe each piece of information they have and use the information obtained quickly. The complexity of their thinking will be higher.

The materials of Real Analysis, such as: algebra sets, functions; mathematical induction; properties of $\mathrm{R}$; and sequence, have been studied in Calculus courses. However, in the Real Analysis, those materials more emphasize on the analysis of concepts. Moreover, The materials in Real Analysis contains the definitions and theorems that must be proven by analysis. The example of the question is

$$
\begin{gathered}
\text { If } \mathrm{A}, \mathrm{B}, \mathrm{C} \text { are supposed to be any sets, show that } \\
\mathrm{A} \cap(\mathrm{B} \cup \mathrm{C})=(\mathrm{A} \cap \mathrm{B}) \cup(\mathrm{A} \cap \mathrm{C})
\end{gathered}
$$

To solve above problem, the students must understand the definition of the intersection and union of the two sets and perform a preliminary thinking/analysis process. After the preliminary analysis, students construct the proof based on the preliminary analysis [2].

Students often become frustrated while composing the preliminary analysis. They have difficulty in examining the proof of a problem especially in composing preliminary analysis. Refer to the reference number, as in [1], the cause for this case is "Students studying real analysis for the first time usually do not have much experience in understanding (not to mention constructing) proofs".

Students have difficulty [3] in structuring their logical mindset in conducting the reasoning in the preliminary analysis stage. They have difficulty in seeing the relationships between definitions and theorems, and the hierarchy of their descriptions. Even though the structured mindset is very important to be possesed by mathematics students in order to solve the problems that require a proof. In addition, students are still constrained in stating the reasons for each statement made. They only understand the procedure of proof, but do not understand every step of the procedure. As a result, students have difficulty in finding out the solution of the problems that require a proof. Students have difficulty in connecting between statements given the logical reasoning of the given

Difficulties students in composing the preliminary analysis will affect their ability in constructing a proof, which is the answer to the given problems. Thus, if given a problem of proof, students will solve it by memorizing.

The completion of a proof presented in most books [4] does not clearly explain the reasoning process, so the students do not understand the analysis of their thinking. In the other words, Real Analysis lessons are less meaningful for the students. This is the cause of the low interest and achievement of the student while learning in Real Analysis lecture.

Based on the review of characteristics of the problem in Real Analysis, the solution given to the problem is the use of Flow Proof in composing preliminary analysis. Students' ability to solve problems that use the Flow proof will help 
them to train their critical thinking, which is used in deductive processes and structuring the mindset logically. Thus, the purpose of this research is to reveal students' ability in analyzing proof using the Flow Proof to solve the problem in Real Analysis lecture.

\section{METHODS}

The type of research this is quasy experiment. The design used [5] is one shot case study.

The subjects of the research were all students of Mathematics Program, Mathematics Department of FMIPA, Universitas Negeri Padang registered on Real-Analysis-I lecture by January - June 2018. The number of subjects involved was 36 students.

In this research, the use of Flow Proof adjucted to the characteristics of the analysis in the Real Analysis. The Flow Proof is [6] sequenced logically according to the procedure of thought. The sequence of thought procedures is intended to solve the given problem. The terms of the relationship are as followings.

- Symbol $\Rightarrow$, indicating the relationship of implications. The relationship shows a causal link that only applies in one direction. This can be identified by a theorem, lemma, or logical arguments. The relationship can be expressed as "if ... then ..."

- Symbol $\Leftrightarrow$, indicating the relationship of equivalence. The relationship shows a conjunction of the two implications. This can be identified by a definition, theorem, or lemma. The relationship can be expressed as "... if and only if ..."

- Symbol $\rightarrow$, shows an alternative relationship. The relationship can be expressed as "... or ..."

During the lecture, the observations on the draft of Flow Proof made by the students to solve the given problems were conducted. The indicators of the design truth as well as logical and systematic thinking ability made by students for every problem can seen from the correct answers they gave in determining :

1) What is known from each given problem.

2) What will be proven from every given problem.

3) What analyze the linkage of theory to find the idea of problem solving.

To achieve the research objectives that have been determined, data collection tool in the form of observation sheets and test result sheets were used. The observation sheets were used to find out the correctness of the Flow Proof design made by the students in terms of logic, material, and solution of the given problem as well as to examine students' ability to solve a problem. The test result sheet is used to know students' mastery of the lecture materials that have been given in the lecture of Real Analysis I.

\section{RESULTS AND DISCUSSIONS}

The result of observations on students' ability to solve the problems revealed that the students made several types of mistakes. These mistakes occured while using logic rules, reasoning, definitions / theorems, and the rules of proof. Mistakes in the use of logic rules generally occured in the negation rule of a statement. Based on the result of the observations, it was seen that $38.9 \%$ of the number of students still cannot use the rules of logic. The example of these mistakes was as following.

$$
\mathrm{x} \notin(\mathrm{A} \backslash \mathrm{B}) \Leftrightarrow \mathrm{x} \notin \mathrm{A} \text { and } \mathrm{x} \in \mathrm{B}
$$

Students should prove,

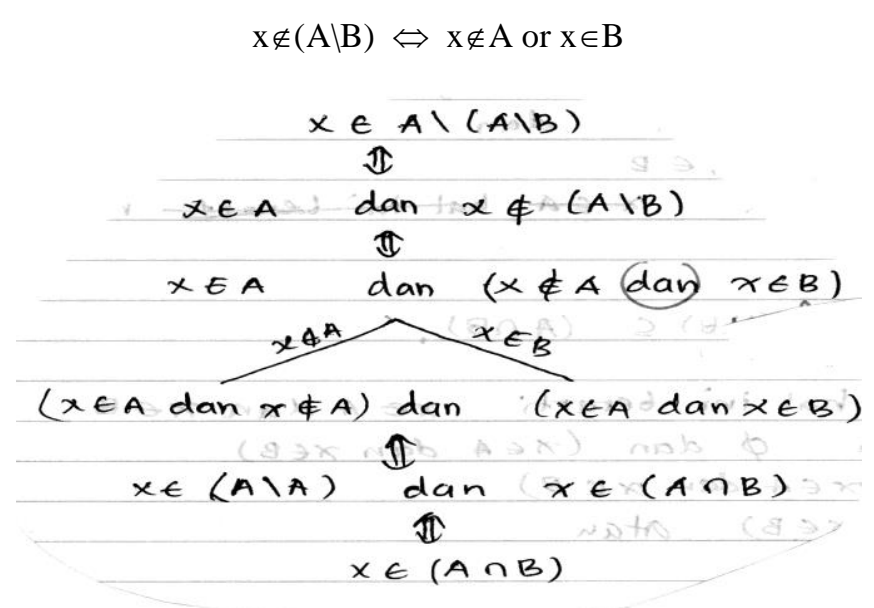

Fig. 1. Example of mistakes in the use of logic rules

Another mistake made by the student was

$$
\begin{aligned}
& \mathrm{x} \notin(A \backslash B) \Leftrightarrow \mathrm{x} \notin \mathrm{A} \text { and } \mathrm{x} \notin \mathrm{B} \\
& \mathrm{x} \notin(\mathrm{A} \backslash \mathrm{B}) \Leftrightarrow \mathrm{x} \in \mathrm{A} \text { and } \mathrm{x} \notin \mathrm{B} \\
& \mathrm{x} \notin(\mathrm{A} \backslash \mathrm{B}) \Leftrightarrow \mathrm{x} \in \mathrm{A} \text { and } \mathrm{x} \in \mathrm{B}
\end{aligned}
$$

Mathematical reasoning occured [7] when students

1) observe patterns or order

2) formulate generalizations and conjectures with respect to observed regularity

3) assess / test conjecture

4) construct and evaluate mathematical arguments

5) illustrate (validate) logical conclusions about the number of ideas and their interrelationships

In additions, the mistakes in reasoning occured at the conclusion of a statement and the presence of a jump in the analysis process. The result of the observations also showed that that $44.4 \%$ of the number of students did not make mistakes in reasoning. The example of mistakes in reasoning made by students was as following.

$$
\begin{gathered}
\mathrm{x} \in \mathrm{A} \text { and } \mathrm{x} \in \mathrm{B} \Leftrightarrow \mathrm{x} \in \mathrm{A} \text { and }(\mathrm{x} \notin \mathrm{A} \text { and } \mathrm{x} \in \mathrm{B}) \\
\varnothing \text { and } \mathrm{x} \in \mathrm{A} \cap \mathrm{B} \Rightarrow \mathrm{x} \in \mathrm{A} \cap \mathrm{B} \\
\mathrm{x} \in \mathrm{A} \backslash \mathrm{A} \text { and } \mathrm{x} \in \mathrm{A} \backslash \mathrm{B} \Rightarrow \mathrm{x} \in \mathrm{A} \backslash(\mathrm{A} \backslash \mathrm{B}) \\
\mathrm{x} \in \mathrm{A} \text { and } \mathrm{x} \in \mathrm{B} \Leftrightarrow \mathrm{x} \in \mathrm{A} \text { and }(\mathrm{x} \notin \mathrm{A} \text { and } \mathrm{x} \in \mathrm{B})
\end{gathered}
$$




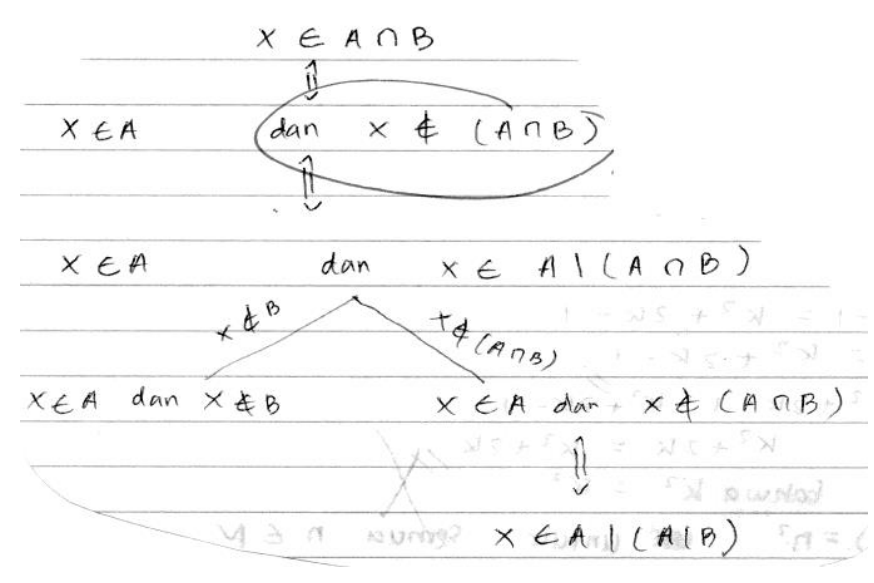

Fig. 2. Example of mistakes in reasoning

Furthermore, the mistakes relating to the definition / theorem occured in the use of definitions. These mistakes were done by $11.1 \%$ of the number of students. The example of this mistakes was as following.

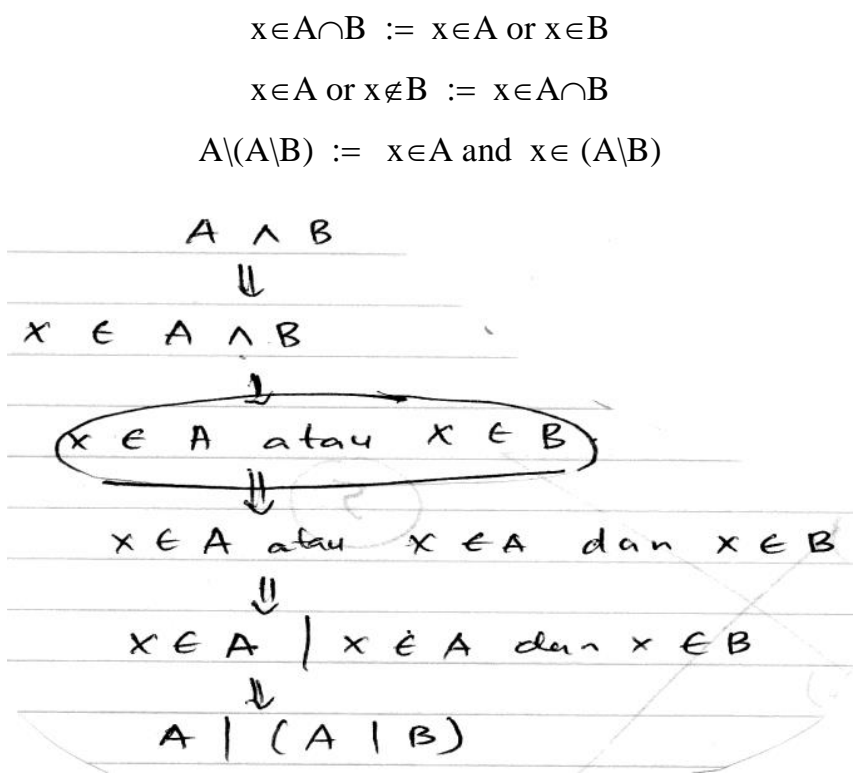

Fig. 3. Example of mistakes in the defining

Finally, the mistake regarding to the rule of proof occured While students solve the problem below.

$$
\mathrm{A} \cap \mathrm{B}=\mathrm{A} \backslash(\mathrm{A} \backslash \mathrm{B})
$$

Students should prove

$$
\mathrm{A} \cap \mathrm{B} \subseteq \mathrm{Al}(\mathrm{A} \backslash \mathrm{B}) \text { and } \mathrm{A} \cap \mathrm{B} \supseteq \mathrm{A} \backslash(\mathrm{A} \backslash \mathrm{B}) .
$$

In this case, only $63.9 \%$ of the total number of students did it correctly.

Students' ability to perform a preliminary analysis using flow proof as well as students' learning outcomes can be seen in Fig. 4.

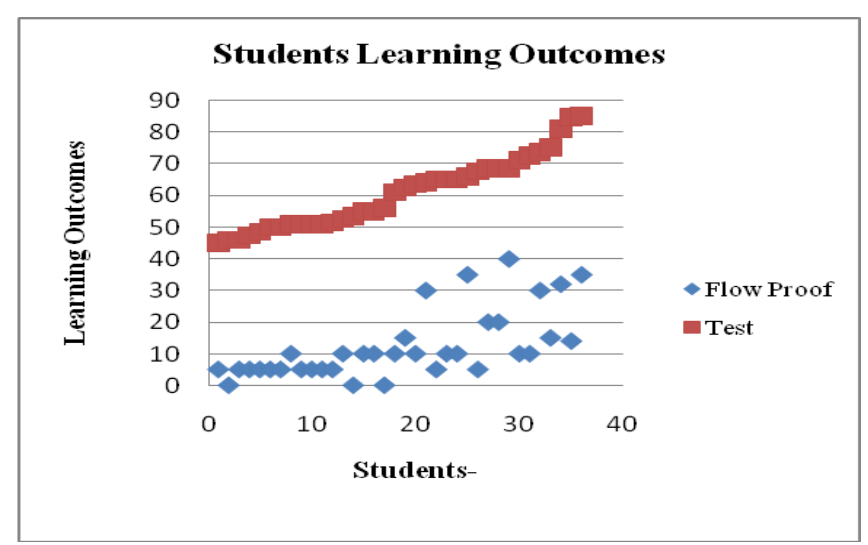

Fig. 4. Students Learning Results

Based on Fig. 4, it can be argued that students' ability in making flow proof of the preliminary analysis affected the learning outcomes. The relationship of these effects in simple linear regression [8] is

$$
\text { test }=50.9+0.780 \text { flow proof }
$$

In this case, the variation in the $53.4 \%$ learning outcome was determined by students' ability to make the flow proof, while the percentage of $46.6 \%$ was determined by other factors.

The ability of students in narrating the proof was still very low even though they have been able to analyze the idea of the proof through flow proof. This meant that the ability of students to communicate mathematics in writing according to logic and critical thinking flow still cannot be done optimally.

If Fig.4 above was more closely scrutinized in each section, it appeared that students who belonged to middle achievers or high achievers had the ability to make better flow proof. This ability affected their ability to narrate proof. This finding was line with the conclusion of the research [9], that by constructing Flow Proof and Two-Column Proof diagrams, it can be seen that students can complete the proof; and it was suggested that students should be given an opportunity to make excuses of a conjecture and evaluate mathematical arguments and prove it.

If the above symptoms were analyzed further and were related to the characteristics of the Real Analysis course I, it can be explained that students who learn by memorizing and lack of the sharp logic will have difficulty in solving the problem if only the problem must be solved by using logic. Students, who already had a sharp logic to solve a problem, at first, are still constrained in using logic in a logical and systematic sequence. After using the flow proof aid, students' ability in performing proof showed better results.

The conclusion of the study by [10] also showed that the use of Flow Proof can overcome students' difficulties in performing proof. Similarly to research by [11], the use of Flow Proof with open problems encouraged student's development toward understanding the structure of proof by providing assumptions with conclusions.

Based on the above statements, it can be concluded that

1) Flow proof can be used to train student's logic to be more systematic and logical in solving a problem in the course of Analysis of Real I. 
2) Flow proof can be used as a means to generate the potential of students having well-logical ability.

So, if the students made the proof based on the flow proof that was correct in both material and logical statements, then it can be said that the students were able to solve the problem well. Thus, the ability of students in solving problems in Real-Analysis-I lecture can be improved by using flow proof.

\section{CONCLUSION}

Based on the results and the discussion of the research, it can be concluded that the use of flow proof in Real-AnalysisI course of Mathematics Program, Mathematics Department of FMIPA, Universitas Negeri Padang registered by JanuaryJune 2018, can improve students ability to solve problems.

\section{REFERENCES}

[1] R. G. Bartle, and D. R. Sherbert, Introduction to Real Analysis, Second Edition, John Wiley \& Sons, Inc: Singapore, 2011

[2] Helma, Penggunaan Model Pembelajaran Aktif Diiringi Dengan Pemberian Lembaran Soal Belajar Aktif (LSBA), FMIPA Universitas Negeri Padang, 2002.
[3] Mukhni and Helma, Peningkatan Kualitas Perkuliahan Analisis Real I Melalui Implementasi Model Pembelajaran Aktif Menggunakan ALPS Berbasis Logical Mind Mapping, FMIPA Universitas Negeri Padang, 2008.

[4] Helma and M. Subhan, Upaya Meningkatkan Kemampuan Mahasiswa Dalam Menyelesaikan Permasalahan Pada Perkuliahan Real Analysis I Dengan Penggunaan Mind Mapping dan Dipresentasikan Dalam Bahasa Inggris, FMIPA Universitas Negeri Padang, 2010.

[5] Sukmadinata and N. Syaodih, Metode Penelitian Pendidikan, PT Remaja Rosdakarya, Bandung, 2006.

[6] MathBitsNotebook, Types of Proofs-MathBitsNotebook (Geo-CCSS Math), https://mathbitsnotebook.com, Januari 2018

[7] National Council of Teacher Mathematics, Principles and Standards for Schools Mathematics, USA : Reston. V.A., 2000.

[8] D. E. Giles, Reverse Regression. Econometrics, Beat: Dave Gile's B $\log / 2014$

[9] M. Cirillo and P. G. Herbst, "Moving Toward More Authentic Proof Practices in Geometry", The Mathematics Educator, 21, 11-33, 2011.

[10] M. Miyazaki, T. Fujita, K. Jones, and Y. Iwanaga, "Designing a Webbased Learning Support System for Flow-chart Proving in School Geometry”. Digit Exp Math Educ, 3, pp. 233-256, June 2017.

[11] M. Miyazaki, T. Fujita, and K. Jones, "Flow-chart Proofs with Open Problems as Scaffolds for Learning About Geometrical Proofs". ZDM: International Journal on Mathematics Education, 47, pp. 12111224,2015 